\title{
Our Project for the New Society in Latin America: The Regulating Role of the State and Problems of Self- Regulation in the Market
}

\section{Franz J. Hinkelammert}

\section{$\mathrm{L}$}

ATIN AMERICAN DEVELOPMENTALUSM IN THE 1950S AND 1960 S PERCEIVED THE STATE as performing a necessary function. It believed that the market, despite its self-regulating capacity, was not capable of assuring development and solving the serious socioeconomic problems that had arisen throughout the continent. The market was understood to distort social relations and, in the circumstances of Latin America, to lead to economic stagnation.

Beginning in the 1970s and with particular force during the 1980s, there appeared an ever more aggressive denunciation of the state and of its regulating role in modern society. If in the 1950 s and 1960 s, the state was assigned a key function in the economic and social development of society, in the 1970s and 1980s the state was designated as the culprit responsible for the major problems that arose in these decades. There is an increasingly negative assessment of the state. The state is now to blame for everything. If there is no development, it is the state's fault. If there is unemployment, the state is also to blame. If there is destruction of nature, errors of the state are responsible. Ronald Reagan. in his 1980 electoral campaign, summed up this attitude with the phrase, "We don't have problems with the state; the state is the problem."

This fixation on the state as the source of everything bad is simply the flip side of a contrary fixation on the market as the solution to all problems. We could alter the expression cited above to show what I mean: We don't have to solve problems, the market is the solution to all problems. In the face of the state as Evil incurnate appears Good: the market is now considered to be a perfect institution, whose affirmation is sufficient to make all problems disappear.

This Manichean negation of the state reveals a deep statism in reverse. If we wish to define statism as an attitude that seeks to find in the state the solution to all problems, in this reverse statism we simply see the state inverted and

Franz J. Hinkelammert, the author of numerous books, is a researcher at the Depanamento Ecuménico de Investigaciones in San José, Costa Rica (Apdo. Postal 389. 2070 Sabanilla. ১an josé, Costa Rica). Translated by Ed McCaughan. 
transformed into the source of all problems. The state continues to be everything and the Manichean negation has not changed what is a deeply statist attitude in relation to the state.

Thus appeared in recent decades a metaphysical antistatism, which is the flip side of total affirmation of the market. This antistatism dominates the current debate about the state and has become a leitmotifof today's worldview. It appeared first in the neoliberal theories about the economy and society and has become today a kind of common sense of public opinion the world over. It even appears in the socialist countries and dominates a majority of the international institutions that make policy decisions.

In no way has this antistatist politics diminished state activity. Yet it has restructured the state. The repressive forces of the state have grown to the extent that the state has ceased to carry out its social and economic functions. In the name of antistatist ideology, the police state replaced the social state. Antistatist ideology served as a smoke screen to hide the unlimited exploitation of the state by international and national economic powers. We are dealing with a tendency that began with the wave of national-security dictatorships in the 1970s in Latin America and continues today despite all the democratizations. The nationalsecurity dictatorships were followed by national-security democracies (see Hinkelammert, 1987).

\section{The State in Central America}

In Latin America the generalized denunciation of the state has taken place in states that are not very developed and are only very precariously institutionalized. There are few states with the capacity to carry out rational action in an entire country or even in parts of it. Perhaps Chile and Uruguay have more developed states, but in the rest of the continent the state is not very effective and its national presence is on the one hand symbolic, and on the other hand reliant on the presence of its armed forces and repressive apparatus, while the enforcement of state laws is in many places completely ephemeral.

If this is true for Latin America in general, it is even more the case in Central America, with the possible exception of Costa Rica. In Nicaragua, during the Sandinista government, there was for the first time a certain level of state development, but in other countries the state is imposed from above, effectuated by the armed forces, and symbolized by the flag, the national anthem, and the Catholic Church. In general, the situation is much like that of the 19th-century states in which there were only two institutions with national validity: the army and the Catholic Cluurch. Although the position of the Catholic Church is being rapidly weakened, it remains symbolically the only national representative - alongside the army - cupable of exercising force. Despite the big differences among some countries, above all in comparison to Costa Rica, this continues to be the general tendency.
These precarious states have a strong tendency toward authoritarianism and uraditionally have been dominated by military dictatorships. When parliamentary democratic regimes have periodically emerged, they have generally been oligarchic democracies subject to being swept aside at any moment by new military dictatorships supported by the same oligarchies.

This is why there is a strong tendency in Central America to base the legitimacy of the existing order on the presence of the army. The inability of the state to carry out normal state functions forces it to be an authoritarian state. This lack of state development can be seen in many parts of Central America, although signiticant differences exist between countries. The states cannot even formulate long-term economic and social strategies. Where there are efforts by planning ministries to formulate such plans, they never become policy, but remain mere declarations of intent. The education systems are incapable of meeting the needs of the countries, while their health systems are unable to service the entire population. The economy develops by chance and, for lack of a national economic policy, follows the lead of the core countries and the international institutions dominated by them. Nor is it possible under these circumstances to have a strategy of scientific or technical development. Such things are constantly discussed, but there is no political ability to carry them out.

This lack of state development is particularly visible in two important places. The armies of Central America are not even able to carry out regular militiry recruitment, despite the fact that they are the national institution with the grealtest presence throughout the society. Thus, recruitment is still carried out by kidnapping, except in Nicaragua where the Sandinista government stopped this pracice. Recruitment is carried out through assaults on the places where young people get logether (dance clubs, movie theaters, carnivals, training seminars, etc.) and they are taken by force back to the barracks. A few days later the families are informed. Families with influence can get their sons out. The others retum only after having completed their military service.

Collecting taxes presents a similar situation. Taxes are levied not where there is income, but rather where someone for whatever reason has to take out his wallet or is faced with an urgent situation. That is why state incomes relies so heivily un sales taxes, customs fees, departure fees, and all types of state transactions, which provide an opportunity to force a citizen to pay. However, direct taxes are very licw. Sularied employees are taxed, but taxes are almost nonexistent for those in hichincome brackets. In any event, tax evasion is the rule, not the exception. Just als the recruits run so that the army can't find them, incomes run so that the state can I lux them. The state is not able to force payment of taxes and evasion is not proseculcd with sensible penalties. The laws of the state are for those who have no escape. hut by no means are these laws enforced universally. Clearly, in a situation likc inis, the state can only defend the existing order with the presence of the army, whose high-level importance and repression again attest to the fact of a weak ind 
undeveloped state, rather than a strong state.

The case of Costa Rica is the exception that confirms the rule. Costa Rica is the only country in Central Ainerica where the presence of repressive apparatuses is not very notable and where as yet there exists no army. However, Costa Rica is simultaneously the country with the most developed state in the region. This can be seen in a school system that covers the entire country and has a certain diversification, as well as in the health system with similar characteristics. The nationalized bank gives Costa Rica a tool with which to carry out an economic policy guided by a strategy, resulting in economic development with much greater equality between the city and the countryside than exists in the rest of the region. Costa Rica also achieved a high level of legitimacy for the existing order based on consensus. As a result, the nation can exist without a large army that would compensate for the lack of a developed state with an authoritarian regime. This fact explains the long democratic tradition of Costa Rica, the basis of which has been explains the long democratic tradition of Costa Rica, the basis of which has been basic functions of the state in defining strategies for the economy, education, and health care; and a much more balanced distribution of income than in the rest of the region.

In Central America, as in Latin America generally, the armies visibly devour their countries. They destructively consume the economic surplus, paralyzing development. The existing order, which they stabilize, is an order without a future, in which the oligarchies together with the armies destroy the future. That is why, to the extent that Costa Rica has escaped such tendencies, it could manage to avoid the emergence of an army and to channel economic surplus through the state toward the tasks of development.

Where the state has fully developed its functions, the role of the repressive apparatuses is more subordinate than dominant, whereas where the state has not developed sufficiently, these apparatuses become the dominant power of the state. From this comes the tendency toward the authoritarian state.

In the absence of state development in Latin America, as in Central America, the prevalence of military dictatorships traditionally has assured the continuity of the existing order. However, to a large extent it is these same armies, which stabilize order, that make development in their countries impossible. By unproductively destroying the economic surplus, they eliminate the possibility of future development.

Metaphysical Antistatism vis à vis the Development of the State: Civil Society and the State

Metaphysical statism is the response that arose in the 1970 s and 1980 s to the development of civil society and the state in the 1950s and 1960s. The decades of the 1950s and 1960s were decades of development in Latin America. It was a period of economic, social, and political development aimed at establishing a

consensus that would support the stability of the existing social system. To achieve this consensus, industrialization was promoted within the framework of complete state planning, and at the same time the state was being developed in terms of a social state (labor laws, education and health systems, agrarian reform, etc.). This state development encouraged the development of civil society at the level of libor unions in industry and in the countryside, neighborhoods, cooperatives, and youth organizations. A broad civil society emerged, with its demands vis à vis the corporate world and the state.

The policy of industrialization was based on import substitution and it resulted in rapid industrial development in many countries. However, when this policy entered into crisis and stagnation, conflicts emerged at the level of civil society that rapidly extended to the political terrain. Tendencies toward increased unemployinent and income concentration at the end of the 1960s subverted the consensus about the social system, and the democracy of universal suffrage produced majorities that tended to break from the consensus. This crisis appeared not only in all of Latin America, but also in core countries, where the 1968 student rebellion revealed a crisis of legitimacy, which is a crisis of consensus. The core countries were able to overcome this crisis, but in Latin America, the response was extreme and led to a rupture with the entire existing democratic system. The politics of consensus was abandoned in favor of the violent imposition of capitalism under threat.

National-security dictatorships emerged that were different from the traditional type of military dictatorship in Latin America. The new dictatorships were highly ideological and even metaphysical in comparison to the tradilional diciaIorships that simply supported the status quo. The national-security dictatorships defined a new relationship with civil society and the state based on military power supported by systematic state terrorism.

These dictatorships became the representatives for metaphysical antistatisin in Latin America and they also emerged in the 1980s in Central America (Honduras, Guatemala, and El Salvador). Although they often operated with a democratic façade, they acted like the national security dictatorships of the 1970s in the countries of South America. Supported by state terrorism, they imposed by force an economic system that abandoned any consensus of the people.

In the name of antistatism, the national-security dictatorships performed in a double sense. On the one hand, they destroyed civil society as it had emergeu in previous decades. They destroyed the popular movements in all their manilestalions - trade unions, cooperatives, neighborhoods. They also destroyed the social organization stemming from the agrarian reforms in the countryside. Likewise. they destroyed the political organizations that were generated in connection with this civil society. On the other hand, they destroyed the activities of the state mat had accompanied and mediated this civil society, i.e., the ability of the state to devise an economic strategy and the health and education systems. All wi this 
destruction was carried out in the name of dismantling the state and of privatizing its functions, a line of action founded on the truly metaphysical antistatism of the repressive apparatuses.

Of course the state neither disappeared nor diminished. What emerged was a different state. The previous state sought a popular consensus. Thus, it developed functions that at the same time promoted civil society. The new state was a state of violent imposition, which renounced popular consensus in order to destroy the capacity of civil society to resist or oppose the state policies inspired by the politics of the total market. The new state was the enemy of civil society, which it reduced to private enterprise operating in terms of market relations.

The concept of civil society that resulted from this process is very similar to that of the 19th century. That concept appeared at the beginning of the last century and it referred to all social activity not initiated or influenced directly by the state. Given the low level of social development of European societies at that time, in practice civil society was identified with the sphere of operations of private enterprise. The German language even expresses this directly. In German one talks about bourgeois society, bürgerliche Gesellshaft. This conception of civil society corresponds to the reality of authoritarian democracy as it operates today. It is about a clearly classist civil society in which only the bourgeoisie has a voice and is taken into account.

During the 19th century, civil society developed, and, by the early 20th century, it could not simply be identified with bourgeois society. Alongside private enterprises had appeared a large number of popular organizations, especially unions and cooperatives, which found political expression through the socialist parties, and which pressed for universal suffrage. Civil society ceased to be the sphere of a single class as other organized classes emerged. A conflict appeared in the heart of civil society, which was primarily a class conflict.

As the bourgeois state came to recognize the legitimacy of this conflict, it began to relate to the conflict by developing new functions for the state, subsequently achieving the establishment of a new consensus that did not eliminate the conflict, but which channeled and institutionalized it. Where this did not occur, the first violent bourgeois states appeared with the intention of completely suppressing the conflict. This was the case of the fascist states that emerged between the two world wars. After World War II, a reform-ininded bourgeois state was imposed throughout western Europe. The functions of the state and civil society developed in tandem, and the fulfillment of state functions made possible the further development of civil society. The relationship between the two is at the base of the democratic consensus in western European societies after World War II, and of their electoral democracy with universal suffrage. This was the type of consensus that Latin America attempted to establish in the 1950s and 1960s, a line pursued as well by the Alliance for Progress.

The metaphysics of antistatism was imposed in the 1970s and 1980s, when capitalist society broke this consensus and returned to the imposed establishment of its pure and open relations of production. Apparently it had returned to the 18 th and 19th centuries. Actually, the political economists of that time, especially Adam Smith, had already developed the theoretical basis for this antistatism, from which they concluded that what was needed was a minimum state (a guardian state). The current return to Adam Smith as the classic of economic thought can be seen in this return to his antistatism. However, today the same thesis of antistatism is even more extreme than it was in past centuries. In the 18th century, capitalist society confronted a past feudal society, which it destroyed in the name of antistatist slogans. Feudal society had neither the power nor the hope to resist. The new civil society had not yet been borne. The bourgeoisie was in fact the only organized social class and it did not need development of the state. It restricted the state to the function of applying bourgeois law internally and to the army for its foreign relations.

In that situation, antistatism did not reach the metaphysical levels it has taken on today, with bourgeois society destroying a civil society that has developed within it. Today, when the national-security dictatorships confront the popular movements so as to destroy them, they are up against organizations that emerged as part of bourgeois society itself. Therefore, the aggressiveness is even greater and the formulations of antistatism are more metaphysical.

\section{The Resulting Neoliberal State}

Thus, it is not a matter of simply defending the state, as though some kind of statism were the solution to the dangers of antistatism. To assure the functions of the state today implies a particular position vis à vis the functions of the market and the development of civil society. There must be a response to the crisis provoked by the policy of dismantling the state and development policies.

The periods of vigorous development in Latin America were periods of high state activity and important state interventionism, to which private enterprise responded with significant force. With the beginnings of the dismantling of the state, however, began the stagnation of the Latin American economy and its failure to develop the continent. Profits rose enormously, but so-called private initiative turned out to be highly inefficient in developing these countries. This led to the coincidence of a rapid dismantling of the economic and social state in the 1980)s together with an ever more notable stagnation of economic development and of the dynamism of capitalist enterprises. This nevertheless occurred in tandem with ever greater increases in the profits of these same enterprises. The inability of private enterprise to develop the countries of Latin America did not lower its profits, but rather increased them.

As stagnation increases, there is yet more talk about the need to further privatize the economic and social functions of the state. There can be no doubt that the dismantling of the state will produce even higher profits than befure. The 
privatization of activities such as health care and education, as well as of public enterprises, allows for private profits to be made in areas that until now were run by the state.

This privatization of state activities leads the state, on the one hand, to concentrate on repressive functions, which absorb increased portions of the public budget. However, privatization does not simply reduce the state to repressive activities. In fact, the state becomes increasingly a lool for economic gain by the ruling classes. The state no longer carrics out its functions, but it continues to be used. Today, the most extraordinary subsidies are paid not to those sectors that have fallen behind, but instead to the most powerful. These subsidies are now called incentives. The change of terminology hides the reorientation toward a state to be exploited for economic gain. These "incentives" far exceed the amounts once spent on the "subsidies," which have been eliminated with such fanfare. When Latin America's foreign-debt crisis came to a head in 1982, all the governments on the continent transformed the foreign debt owed by the private sector to the private international banks into a public debt guaranteed by the state. A large portion of this debt would otherwise have ended in simple bankruptcy. However, under pressure from the U.S. government and the International Monetary Fund (IMF), Latin American states felt obliged to assumed responsibility for the debt. More than half of Latin America's current foreign debt is a result of this state intervention, which amounts to a gigantic subsidy of private international banks. In the 1980s, other subsidies/incentives were added to encourage exports - in many countries amounting to five percent of the national product. A large portion of these payments goes to the multinational corporations operating in Litin America.

A similar situation is apparent in foreign debt-swap arrangements. Debt swaps have become one of the big speculative businesses in the region and are subsidized by the states. They have become a source of state subsidy for private activities, which fall completely outside the mechanisms of national and parliamentary decision-making and which open up enormous spaces for arbitrary and discretionary decisions by the presidents of the central banks and finance ministers.

In a recent publication, CEPAL (the Spanish acronym for the Economic Council for Latin America) provided data that allow us to see how the debt swaps work. Foreign institutions or organizations buy titles to the foreign debt owed to creditor banks. A nominal value is given to the titles, which are sold by the banks in the secondary debt markets at real prices, generally below the nominal value. CEPAL analyzed nine cases of debt-for-nature swaps in Latin America iCEPAL. 1991: 116).1 The foreign institutions bought a nominal total of $\$ 90$ million on the parallel market for a sum of $\$ 14$ million. The titles are presented to the central bank of the debtor country, which buys them for a given amount in the national currency. Depending on the case, the central bank can recognize the titles for as much as the limit of the nominal value. The decision is completely arbitrary. In the case analyzed by CEPAL, the titles were purchased for a sum in national currency equivalent to $\$ 53$ million, i.e., nearly four times the real value in the secondary murkets. The difference is financed by the state, which in the case analyzed by CEPAL means a subsidy of nearly $\$ 40$ million. Yet no subsidy to anyone appears on the balance sheet of the central bank, which financed the exchange. To the contrary, in the bank's balance sheet the titles of the debt are recorded at their nominil value, the result of which is that the subsidy becomes a profit in the books of the central bank. To use this example, according to the bank's balance sheet, the central bank made a profit of $\$ 47$ million by paying only $\$ 53$ million for titles to the foreign debt worth $\$ 90$ million.

CEPAL only provided information for those debt-for-nature swaps. This was also for psychological reasons, since public opinion tends to view public subsidies favorıng nature positively. However, even in this case the swap is problematic, becuuse now foreign entities are determining where the state will and will not be active.

Obviously the problem is much more complicated when the debt swaps are not for nature, but for other purposes. Today we have debt conversions for many different lypes of activities. In several countries, foreign financing of churches and even political organizations is transferred through debt swaps. Under such arrangements, these organizations receive enormous support, which assures them an exchange rate for their funds in hard currency several times higher than the market rate of exchange. Nevertheless, the decision about receiving such support is taken by very small groups, often only by the president of the central bank, who lacks the legitimacy to make such decisions.

The most telling case of subsidies for debt swaps, however, is conversion for national industries, which are purchased for sums far below their market price. This occurs above all in the privatization of state industries. By accepting payment for debt conversion, the state provides extraordinary subsidies to the buyers, be they national or foreign.

Today in Latin America, some $30 \%$ to $40 \%$ of state income is spent on servicing the debt, including necessary payments for debt conversion, and the tendency is increasing. Clearly, these payments are being made in place of those that were formerly made for carrying out the functions of the state. Together with the costs of the repressive apparatuses, the costs of debt service are considered top priority. The bureaucratic apparatus of the state consumes a good part of what remains of the budget, leaving very little for activities such as education, health carc, social security, or public investment programs.

This situation has changed the character of the state. The interventionist state of the 1950s and 1960s was a state that redistributed income in favor of the lowestincome groups. Today's neoliberal state functions exactly in reverse, redistributing income in favor of the highest-income groups at the expense of those with the lowest income. 
This is precisely the effect of the debt payments, whether internal or external. These payments are the result of the fact that in previous periods, the taxes necessary to cover the expenditures of the state have neither been levied nor paid, leading to high state deficits. These deficits were covered through loans. Particularly in the case of the internal debt, high-income groups financed the state deficit with loans rather than by paying taxes. Once the debt had reached sufficiently high levels, debt-service payments on the loans automatically transformed the state into an agency for paying the debt, thus preventing it from carrying out its public functions. Debt service has transformed the state into the payer of transfers from low-income groups to high-income groups. The lower the taxes paid by highincome groups, the greater their ability to transform the state into a source of income redistribution in their favor.

This has occurred not only in Latin America, but also in core countries, especially the United States. State indebtedness, brought about by. the Reagan administration, has paralyzed the U.S. state to such an extent that it will be decades before the state is able to once again act rationally. The military apparatus along with the debt service guarantee that only a minimum state is financially possible. A bourgeoisie that refused to pay its taxes brought the state to bankruptcy and tumed it into a simple collector of payments from low-income groups intended for high-income groups, and from poor countries for rich countries. 2

However, this strangulation of the state also strangles the countries themselves. Higher profits lead not to more development, but to more stagnation. Without a vigorous state to create opportunities and to sustain activities that foment productive private sector activity, private enterprise turns out to be inefficient in directing the development process on its own. The more private enterprise penetrates the entire society, the less it spurs development. Unemployment, pauperization, and the unbridled destruction of nature are the results. Economic growth, which private enterprise so heartily promises, declines instead of increasing.

Yet private enterprise not only destroys development. It also comupts and destroys the state's very capacity for rational action. It corrupts by taking ever greater advantage of the remaining state activities, and it creates such social problems that the state apparatus is forced to take action without the means necessary to do so. Because of its inability to carry out an economic policy of employment and a social policy of income distribution, the state becomes the sole source of income for those not employed by private companies. Since they know not where else to turn, the unemployed pressure the state to find some job - a pressure resulting directly from private enterprise's inefficiency in providing jobs for the population.

Yet the state no longer has any tasks to carry out. Nevertheless, even with its restricted functions, it is obliged to support more personnel, who are really needed to carry out the few tasks that remain. Thus, the state is corrupted from both sides: for the bourgeoisie as a source of ever more illicit income and for the people as a palliative for unemployment and pauperization. The state begins to support personnel who have no functions.

State corruption, demoralization, and inefficiency then become an argument for even further dismantling the state and privatizing it functions. However. privatization just makes the situation worse, since the original cause of stagnation is private enterprise itself. When left on its own and without recourse to the state, private enterprise is unable to come up with an adequate development policy; yet it opposes any rational state action that would limit its ability to profit from the state's inefficiency. This leads to an unending circle with no apparent way out.

This situation can only be sustained through an increasingly more repressive orientation of the Latin American states. Rather than being rationalized, a state that cle irly requires many reforms is increasingly put at the exclusive service of national and international economic powers. Metaphysical antistatism is the nadeology that hides this situation and provides its apparent justification. Everywhere that this antistatism in the name of the total market has been instituted, economic and development crises have been unleashed. Under the guise of the myth that the market can best solve all problems, existing problems have become more extreme. Unemployment has reached levels never imagined, income disuribution condemns ever greater sectors of the population to misery, and the destruction of nature occurs on an unprecedented scale. Nor has the promise of sustained economic growth been kept. Under the aegis of antistatism, economic dynamism itself has been lost. Private enterprise, guided exclusively by market mechanisms, loses its efficiency while increasing profits. ${ }^{3}$

This has occurred even in the core of world capitalism, during the 1980s in the United States. Antistatist politics destroyed the efficiency of the economy there as well, while the capitalist economies with developed states, such as Western Europe and Japan, took the lead. It is the tragedy of Latin America to have fallen for the myth of antistatism only to confirm its decline.

\section{The Future Determination of Society in Latin America}

Nevertheless, the problem is not the market itself, but rather the pretense of transforming it into the perfect society, the only legitimate institution (in whose name the popular movements and the state are destroyed), an institution that lotalizes society. The problem is antistatism, not the market as such. When the market is viewed as a perfect institution, it devours all and becomes a totalitarian subject. It destroys civil society along with the state and it cannot maintain itself except by transforming the state into a terrorist state.

Something similar has taken place in the societies of historic socialism. They transformed planning into their perfect society. In the name of planning, antistausim emerged and became state terrorism. Again, the problem was not planning per se. hut the pretense of transforming it into the perfect society, the only legitimiate 
institution, devouring all other institutions. The state became inoperable and civil society was likewise destroyed.

In the face of these problems, the point is not to search for another perfect society, in whose name society will be totalized, but to renounce the imposition of perfect societies. It is necessary to stop trying to destroy the state or the market and to recognize that the conception of perfect societies as a principle of politics destroys society itself. There is not and cannot be a perfect society. There is not and cannot be a single institution that totalizes society. We no longer have to make such claims about the state or planning; everyone today is convinced that these institutions cannot constitute the perfect society. However, it is necessary to make this case about the market. Today, the market appears again as the totalizer, the only legitimacy in society, the institution that has the right to sweep aside all others and even life on earth.

To meet the demands of human life on this earth that all of us must live upon today and tomorrow, what we need is a political synthesis that gives the various institutions their place and task. Today the starting point would be the recognition that men and women who work under the exclusive guidance of the market, left to its self-regulating forces, destroy the sources of wealth they produce. Abandoned to these forces, the life of the planet is in danger. In the face of the destructive effects of the market, which automatically accompany its creative powers, arises the resistance of civil society, which takes the form of the most diverse types of popular organization for the protection of both human beings and nature. These popular organizations have a function of rationalizing the market, protecting it through their resistance from the destructive forces it produces. They do not "distort" the market; rather, they act in the face of distortions produced by the market itself.

Yet popular organizations cannot carry out this function unless they have recourse to the state. In its positive functions, the state is the agency of power that could universalize the actions of the popular organizations. Without this universalization, resistance becomes as fragmented as is human activity within the market, and it consequently reproduces the destructive effects of the market without being able to correct them.

The state is the agency that can universalize resistance vis à vis the distortions produced by the market in human relations and in nature. The state has no reason to intervene in markets when they do not produce distortions. Thus, the theory of the functions of the state has to begin with an understanding of the distortions produced by the market. 4

The functions of the state emerge along two lines - in promoting civil society and in planning the economy. In its function of promoting civil society, the state must make possible the development of civil society and open up possibilities for it. This involves. first, the legal existence of popular organizations and the exercise of resistance. Yet it equally involves guaranteeing their economic ability to exist.
Additionally, there are other functions that only the state can perform, in that certain activities need to be universalized and the private sector has been unable to accomplish that. This is especially true in health and education. There will be no universal attention to these needs without the emergence of high-level, public systems of health and education.

In its role of economic planning, the state has to make possible and promote development capable of guaranteeing the economic and social integration of the entire population and its compatibility with the conservation of nature. Perhaps the need for carrying out this function is most visible in underdeveloped societies, where it is apparent that only in very exceptional cases has private enterprise, on its ( wwn and left to the self-regulating forces of the market, been able to guarantee any level of economic development, and where it is even less able to integrate the entire population in the social division of labor. The need for state action is even more visible in terms of conserving nature. Only a planning state can give private enterprise the possibility and the space to carry out its task of economically developing a country. Likewise, only a planning state can assure that economic development respects limitations on human integration into the economy and environmental conservation. Here as well, in terms of the planning activities of the state, its first task is the promotion and support of enterprises. However, the need to universalize development, to respect nature and to protect it for all on behalf of all, also makes necessary the direct action of the state in the economy, through public enterprises and the imposition of guidelines and limitations for investment.

In this way, the problem of the state is a problem of the entire society, in which civil society, the market, and the state interrelate and interpenetrate one another. None of these poles can exist without the others, and even the possibility of human life and of economic rationality itself is a product of these three and their interrelationship such that there is a synthesis instead of the negation of one pole in the name of another. Only with this perspective can we focus on the pending problems of development. We are talking about problems that today cannot be solved by each of the states within their particular frameworks of political domination; rather the problems require the creation of new world orders - in terms of economics, finances, markets, and ecology - without which a policy of rational development is no longer possible.

In Latin America today, and especially in Central America, where society and the state are not very developed, it is necessary to create society itself, together with the state. The task today is to reconstruct society with a complimentary relationship among the noncommercial sectors of civil society, the market, and the state, in which it is possible to reinitiate a path toward development, but this time within the framework of an integration of the whole population in the social division of labor and in society, within the limits of preserving nature. We need to lurn back the process produced by the policy of dismantling the state.

This requires energizing the noncommercial sectors of civil society, which 
were systematically repressed by the terrorism of the national security state. To do so presupposes a state that not only tolerates but also foments this civil society. To bring about the necessary rationalization of the state, however, we also need to elaborate a new development project in which the market and state economic planning are recognized as complementary. Without the necessary component of state planning, the market is not capable of creating economically rational development. 5 Unless it carries out this task, the state has to base itself fundamentally on its repressive forces and tends toward state terrorism. With this exclusive concentration on its repressive strength. the state cannot contain the demands of those dispossessed and displaced by the forces of the market. Since the dispossessed and displaced cannot directly guide the market, they will do so through the state. Since there is universal suffrage, the state can only respond to their demands with a quantitative and irrational extension of the state apparatus, 6 when it is prohibited in the name of antistatism from seeking a solution through a model of development that would permit their integration in the social division of labor through the markets. This inflation of the state is nothing more than a reflection of the inability of the market to automatically resolve people's economic problems. The most probable outcome is the transformation of the state into an exclusively repressive state, in the name of its rationalization.

Thus, the motto vis $a$ vis the state cannot be antistatism. This is not about dismantling the state, but about dismantling the armies and the repressive police forces, reducing them to the minimum levels required. The necessary reform of the state, therefore, must substitute its repressive function with a development policy that allows for a state equal to the necessary tasks, to the extent that a development policy can respond to the economic needs of the population. We have to choose between dismantling the state and dismantling the repressive apparatuses. Dismantling the state leads to the hypertrophy of the repressive apparatuses, and the dismantling of these apparatuses presupposes development of the state's ability to carry out its tasks.

This is also a proposal for a democracy that is currently possible. It is the condition that will allow democracy to be viable. ${ }^{7}$ Antistatism combined with the totalization of the market demands that one live and let die. Democracy presupposes that one live and let live.

What is emerging today in Latin America, however, is an aggressive democracy, without consensus, with an extreme control over the means of communication by concentrated economic interests, in which sovereignty is not in the civilian governments, but rather in the armies and in the international financial institutions that represent the governments of the core countries. These civilian governments tend to subject themselves to the sovereign exercise of power on the part of the armies and the police, and in the name of collecting the foreign debt, the dictates of international institutions. These are controlled democracies, whose controllers are nol subject to democratic mechanisıns of any kind.

\section{NOTES}

I. Gert Rosenthal, general secretary of CEPAL, says the following of the debt-for-nature swaps:

We think they could be interesting, but they have to be evaluated carefully and case-bycase, and we have two concerns. The first is that [debt swaps] normally involve a considerable fiscal subsidy on the part of the debtor government vis à vis the pany that acquires the debt in the secondary market. The second concerm is that the majority of the Jebt-for-nature swaps that have been undertaken thus far respond to the priority agenda of the donor entily... (El Dia Latinoamericano, 1991).

2. As the neoliberals are wont to do, they made their arguments based on a simple mathematical cur ve that had magic effects on public opinion. It is called the "Laffler Curve." According to this curve. the intentional lowering of taxes paid by high-income groups in the U.S. would, as an indirect the in to ances collected, because it would so thoroughly dynamize the econ 'my that a lower tax rate would still result in a general increase in taxes collected. This "U.S. roulte.e" was an enormous intellectual fraud. Probably the resulting paralysis of the state was exactly the iffect intended by those directing the economy under Reagan. They could in this way force an entire future generation to continue with the same policies of dismantling the state and leave as the only future generation to continue with the same policies of dismantling the state and leave as the only Stockinann, Reagan's budget director until 1986 insinuated as much (Stockmann, 1986)

3. This designates the end of the politics of development and of intemational solidarity. Gert Rusenthal, general secretary of CEPAL, makes this clear:

think that in any relationship between weak and strong, the strong have assets on their side; this occurs at the national level in distributive matters and it occurs in intemational relations among economically strong and economically weak countries, and it occurs in the world order.... Latin America and the Caribbean have to take their destiny in their own hands and resign themselves to the fact that we live in an inequitable world and that we have co function in this world.... [T] his is a cruel world and we have to function in it, like it or not; we are going to try to act collectively (El Dia Latinoamericano, 1991).

4. This explains why any thinking in terms of some perfect institution is antistatist. Clearly, if we assume that the social relations of production function perfectly, we would never discover any role for the state, except its repressive function, which survives because of "egoism and stupidity," as Peter Berger (1971: 44) has concluded. The conclusion simply reveals that it is inspired by thinking in terms of perfect society.

5. The structural adjustment policy currently being implemented throughout the Third World is not a development project. It is the result of having renounced any development project. In our Orwellian language, such a policy, which results from the refusal to make policy, is now called devilopinent policy. War is peace, lies are truth.

h. The developed capitalist countries respond to this same problem by creating a subsidy for uncmployment, which serves as a sort of buffer between the unemployed and the state. However, in uncmployment subsidy has to cover basic necessities. In the countries of Latin America, wages barely cover the necessities. An unemployment subsidy would have to be equal to wages or only slightly inlerior. In societies where wages are substantially higher than this minimum, the subsidy is possible. heciause it does not remove the economic incentive for a worker to seek employment. Yet a subsidy thit is equal to wages takes all economic incentive away from the worker. This explains why in Latun Americil unemployment subsidies hardly exist. Moreover, when unemployment reaches up to $40 \%$ ur SII $i$ if the work force, there is no economic ability to pay a subsidy. This automatically turns peripheral captliltsm intu savage capitalism, when no effective development model has been established. One cillicr hais it job or one falls into misery. The result is the formation of the informal sector of the 
economy. Althou sould not assure formal employment to all, an effective development model has : to foment activities a the informal sector. Otherwise, the formal sector becomes a mere receptacle $\mathrm{for}_{\mathrm{r}}$ : the misery produced by the tendency toward unemployment created by the unbridled market.

7. The problem of the viability of democracy in Central America has been elaborated especially

\section{REFERENCES}

\section{Berger, Peter} 1971

CEPAL

$$
1991
$$

El Dia Latino

$$
1991
$$

inkelam

1987
El dosel sagrado: Elementos para una saciología de la religión. Buenos Aires:
Amarrortu Editores.

El desarrollo sostenible: transformación producriva, equidad y medio ambiente. Santiago, Chile: CEPAL. ambiente

\section{Interview with Gert Rosenthal. (March 19).}

ammert, Franz

Stockmann, David

1986

El Estado de Seguridad Nacional, su democrarización y la democracia liberal en América Latina. San José, Costa Rica: DEI.

Torres-Rivas, Edelberto

1987 Centro América: la democracia posible. San José, Costa Rica: EDUCA.

\section{h}

$\checkmark$

) 